\title{
GABRIELA MARCELA FILOZOFIA WIARY
}

Gabriel Marcel nie ma szczęścia do czytelnika polskiego, w szczególności czytelnika filozoficznego: oprócz paru artykułów oraz dwóch dobrych książek ks. Ignacego Deca, na przestrzeni paru dziesiątek lat odbiór w Polsce myśli Marcela, którego cztery ważne książki zostały przecież przetłumaczone ${ }^{1}$, praktycznie nie istnieje. Winne jest temu w dużej mierze zderzenie się myśli trudnej, niesystematycznej, kładącej nacisk na niewystarczalność tradycyjnie pojętego filozoficznego dyskursu, $\mathrm{z}$ silnie zakorzenionym u nas $\mathrm{w} \mathrm{XX}$ wieku „racjonalistycznym” stylem filozofii, reprezentowanym zarówno przez szkołę lwowsko-warszawską, jak i przez myśl Romana Ingardena, czy wreszcie tomizm. Ale zrozumieć, to - wbrew znanemu powiedzeniu - niekoniecznie usprawiedliwić: w braku recepcji Marcela daje o sobie znać - co najmniej w równym stopniu co tradycja filozoficzna oraz merytoryczne (choć rzadko wypowiadane) zarzuty - zwykłe, nieobecne nam niestety, lenistwo intelektualne.

Warto chyba to lenistwo przełamać i przyjrzeć się innemu niż ten, do którego przyzwyczailiśmy się, stylowi myślenia i to od razu w zagadnieniu szczególnie dla tradycyjnej filozofii drażliwym: zagadnieniu wiary oraz poznania Boga. Może ten skok w głęboką wodę nie okaże się dla czytelnika całkiem bezowocny.

\section{KRYTYKA „RACJONALIZMOW”}

Niewątpliwie głównym motorem poruszającym myślenie Marcela jest budowanie filozofii doświadczenia świata takiej, by ukazać filozoficzną możliW tekście artykułu zastosowano następujące skróty tytułów dziel G. Marcela:

EA - Etre et avoir, Paris 1935.

FP - Fragments philosophiques, Louvain 1961.

HV - Homo viator, Paris 1944.

JM - Journal métaphysique, Paris 1927.

ME II- Le mystère de l'être, t. 2, Paris 1951.

PA - Position et approaches concrétes du mistére ontologique, [w:] Le monde cassé, Paris 1933.

RI - Du refus à l'invocation, Paris 1940.

${ }^{1}$ Homo viator, tł. P. Lu bi cz, Warszawa 1959; Być i mieć, ti. P. Lubicz, Warszawa 1962; Od sprzeciwu do wezwania, tł. S. Ławicki, Warszawa 1965; Dziennik metafizyczny, tł. E. Wende, Warszawa 1987. 
wość rzeczy wist e go, to znaczy os ob is t e go dostępu do Boga, a przez to odsłonić przed człowiekiem współczesnym perspektywę „zbawienia”; nie uważa on a priori, by poszukiwanie prawdy filozoficznej musiało się wykluczać z pewną głębszą, soteriologiczną intencją myślenia. Co innego jednak owa głębsza intencja, a co innego cel bezpośredni: tworzenie filozofii z właściwymi dla niej wymogami ścisłego i w miarę jasnego myślenia, wiernego maksymalnie doświadczeniu, a zarazem pierwotnej filozoficznej - a nie tylko religijnej intuicji, bez której nie można w ogóle wyruszyć w filozoficzną drogę.

Marcelowska intuicja krystalizuje się i uwyraźnia przez konfrontację z różnymi odmianami myśli „racjonalistycznej”. Trzy z nich zasługują tu w szczególności na uwagę: idealizm absolutny, scjentyzm, oraz — tomizm. W polemice $\mathrm{z}$ nimi Marcel buduje swoją ontologię, epistemologię oraz teorię wiary.

Idealizm absolutny rysuje się Marcelowi pod postacią idei „wiedzy absolutnej” reprezentowanej oczywiście głównie przez Hegla. Rdzeń tej idei polega według Marcela na stawaniu się absolutu prawdy — będącej w istocie Bogiem - poprzez ruch dialektycznych triad: tezy (np. bytu), zaprzeczającej jej antytezy (np. nicości) i znoszącej je obie jako samoistne (i w tym sensie nieprawdziwe), ale zarazem je zachowującej jako niesamoistne elementy, syntezy (np. stawania się). To, co w procesie dialektycznym znoszone i zachowywane, jest tym, co skończone jako takie, a czego pojawiający się na końcu procesu „Duch Absolutny” ma być absolutną prawdą i zarazem nieskończoną rzeczywistością. Otóż dla Marcela idea wiedzy absolutnej błądzi podwójnie: z jednej strony zaprzepaszcza samoistność równocześnie tego co skończone (np. indywidualnego ludzkiego doświadczenia) i Boga, który przestaje móc być absolutem $\mathrm{z}$ chwilą, gdy jest jedynie sumą zniesionych i zachowanych skończoności; $\mathrm{z}$ drugiej strony to zaprzepaszczenie jest zarazem wewnętrzną sprzecznością systemu: cóż to za absolut, który jest sumą tego, co nie-absolutne, albo prawda, która jest sumą nie-prawd? W istocie żadna wiedza nie może być absolutna, ponieważ jest zawsze dziełem skończonej ludzkiej myśli (zob. FP s. 44 n.).

Scjentyzm, reprezentowany w czasach młodości Marcela głównie przez Leona Brunschvicga, uważał z kolei, że można filozofować sensownie tylko o tym, co empirycznie sprawdzalne przez potencjalnie nieskończoną ilość doskonale wymienialnych obserwatorów. W poznawaniu czegokolwiek liczy się zatem tylko to, co obi e k t y w ne, a co jest korelatem aktów świadomości umysłu wyzbytego doszczętnie swoich cech indywidualnych, swojego najgłębszego, konkretnego ja. Czy można jednak w ten sposób oddać sprawiedliwość prawdzie naszych najbardziej istotnych, osobistych przeżyć, z których najważniejsze dotyczą naszego stosunku do Boga i do najbliższych nam ludzi? Bóg Brunschivcga jest wyłącznie abstrakcyjnym ideałem - ale czy jest to jeszcze Bóg? I czy można za pośrednictwem poznań obiektywnych, których paradygmatem w nauce współczesnej jest to, co matematycznie wymierne, „przeliczalne”, tworzyć autentyczną wspólnotę międzyludzką, jak głosi ów, rodem pro- 
sto z myśli Oświecenia, scjentyzm? Dla wspólnoty tej ważna jest raczej świadomość „doświadczenia słabości”, podobnych miłości, lęków, nadziei (RI s. 13).

Polemika Marcela z tomizmem ma charakter szczególny, miała bowiem miejsce po jego konwersji na chrześcijaństwo i równolegle do chrztu w Kościele katolickim w marcu 1929 r. (w wieku 40 lat), a więc wewnątrz pewnej podstawowej wspólnoty wiary i wartości. Ale Marcel zarzuca tomizmowi m. in. właśnie to, iż nie docenia wagi tej wspólnoty dla filozofii bytu i Boga. Jeśli tzw. dowody na istnienie Boga są faktycznie tak malo dla ludzi niewierzących przekonywające, to nie dlatego, że zawierają zasadnicze braki w rozumowaniu, lecz ponieważ pomijają jedyną bazę, na jakiej może dojść do porozumienia między ludźmi na temat Boga: wspólny horyzont wartości, a więc wspólną - choć może nieuświadomioną i niewyartykułowaną - w i a r ę. Jeśli chcę komuś udowodnić istnienie Boga (a czymże jest dowód, jak nie dowodzeniem k o m uś), to $\mathrm{z}$ jednej strony jawię się sobie jako wiedzący więcej i w tym sensie „wyższy” od tego, któremu dowodzę, z drugiej strony zakładam, że wystarczy, iż mój rozmówca natęży dostatecznie uwagę, by zgodzić się z moim rozumowaniem i przyznać mi rację. Tymczasem rozmówca mój może n ie ch ci e ć iść za moim rozumowaniem, ponieważ np. nie uważa on Boga za najwyższe Dobro, za które ja Go uważam, a zatem nie podziela mojego, podstawowego i pierwotnego w stosunku do wszelkich rozumowań, wyboru orientacji w świecie, a zatem mojej wiary. Czlowiek nie jest, jak chce tomizm, ponadczasowym animal rationale, lecz żywą choć skończoną w ol n ości ą w konkretnej dziejowej sytuacji. Dlatego mimo szacunku dla św. Tomasza, a także Maritaina i Gilsona, nie wahał się Marcel napisać: „Tomistyczne/ dowody zakładają, że już się uprzednio zadomowiło w Bogu i w gruncie rzeczy polegają na sprowadzeniu na płaszczyznę myśli dyskursywnej zupełnie innego aktu. Nie są to, jak sądzę, drogi prawdziwe, lecz pozorne, tak jak istnieją ślepe okna" (EA s. 141).

Jakie są zaś drogi prawdziwe? Te, które są w stanie pokazać, że niewierzącego być może ożywia sekretnie wiara, z której nie zdaje sobie sprawy, zaś wierzący jest stale zagrożony możliwą, a nawet faktyczną niewiarą. Na to jednak, by to wykazać, potrzebna jest, ni mniej ni więcej, tylko rewizja — choć nie całkowite odrzucenie - całej dotychczasowej koncepcji bytu, poznania, metody filozofowania, a także do pewnego stopnia dotychczasowej filozofii Boga.

\section{TEORIA PARTYCYPACJI}

Dla Marcela wszystkie dotychczasowe filozofie o stylu racjonalistycznym mają jedną wspólną cechę: zbytnie przekonanie do konstrukcji pojęciowych i do abstrakcyjnego myślenia w modus „w ogóle”. Tą drogą nie da się jednak dotrzeć do rzeczywistości przede wszystkim - choć nie wyłącznie - duchowej, a więc i religijnej, ponieważ primo: myślenie pojęciowe zamyka nas w na- 
szych własnych, immanentnych konstrukcjach; secundo: to, co duchowe, ma piętno ściśle indywidualne i konkretne. Czy istnieją jednak inne, a podatne do filozoficznego badania przystępy do rzeczywistości, niż te, które owocują pojęciowymi konstrukcjami? Owszem - stanowią one obiekt tak zwanej przez Marcela teorii partycypacji, której nie przestawał przez całe życie czujnie rewidować i pogłębiać. Teoria ta ma dla Marcela piętno od razu religijne, ale wprędce przekształca się w całościową koncepcję doświadczania świata, w której z kolei myślenie religijne znajduje dopiero swój pogłębiony wyraz. Dlatego zanim przystąpimy do omówienia marcelowskiej teorii wiary, musimy pokrótce zarysować teorię partycypacji z nieodłączną od niej koncepcją nowej racjonalności.

W jaki sposób do teorii tej w ogóle docieramy? Przez stwierdzenie, że skoro wszelka wiedza jest odniesiona do skończonego, ludzkiego podmiotu, to podmiot ten ją w pewien sposób zawsze przekracza, jest w tym sensie wobec niej „wolny”; ale zarazem przecież odnosi się on do rzeczywistości, bez której byłby pusty. Skoro tak, to rzeczywistość ta musi być dla niego czymś innym, niż siecią konstrukcji pojęciowych. Jest ona raczej różnym od wiedzy absolutnej, ale nie oderwanym od niego „byciem” (związanym nie rozłącznie z bytem), w którym podmiot od początku bezpośrednio partycypuje i które może mu się uobecnić w swoistej intuicji, ale nie może nigdy zostać „uprzedmiotowione”, pod groźbą samobójstwa myśli. Podmiot partycypacji jest — powtórzmy - wolny a zarazem zwrócony ku innym wolnościom — stąd waga relacji intersubiektywnych - a zarazem pierwotnie, w cielony.

\section{Egzystencja i diada}

Przypatrzmy się najpierw zagadnieniu „wcielenia”. Polemizując z filozofią idealistyczną, Marcel odkrywa, że podmiot partycypacji be z pośr ednio rozumie nie tylko to, co myślowe, ale także to, przez co bezpośrednio uczestniczy w świecie: swoją cielesność. Ciało nie jest tylko „ciałem w ogóle”, rozważanym przez nauki szczególowe lub rozpatrywanym jako instrument nie wiadomo jakiej fizyczno-duchowej „władzy”, lecz moim ciałem, które odczuwam i poprzez które współ-odczuwam z całością rzeczywistości. Pierwotnym rozbłyśnięciem światła poznania dla człowieka jest $U r$-Gefühl (JM s. 240), praodczuwanie, które jest zarazem nierozerwalną więzią z tym, co istnieje.

Odczuwanie bowiem otwiera przede mną z niezachwianą pewnością wymiar istnienia, które obejmuje od razu niezróżnicowaną cał ość: jest to, po pierwsze, całość mojego istnienia-w-świecie: „afirmacja «ja istnieję» dąży do zlania się z afirmacją «istnieje świat»” (JM s. 313). Po drugie jest to „nierozłączna jedność istnienia i tego, co istnieje" (JM s. 314), której nie da się bez okaleczenia rozłożyć na „istnienie" i , coś, co istnieje” — oto jeden z powo- 
dów, dla których Marcel nie będzie mógł nigdy przystać na słynną heideggerowską „różnicę ontologiczną” między byciem a bytem (choć dla Marcela bycie i istnienie to nie to samo). Istnienie to nie korelat „sądów egzystencjalnych”, lecz w istocie najbardziej podstawowa s y t u a c ja, ,zona przylegania do tego, co nieprzekraczalne, niemożliwe kiedykolwiek do przekroczenia" (JM IX), której dlatego nigdy nie można dowodzić: oto m. in. dlaczego Marcel nie może zaakceptować idei „dowodu na istnienie Boga”.

Dla Marcela ten pierwotny, dany poprzez cielesne odczuwanie rozbłysk światła istnienia ma zarazem piętno in ty m ności. Bowiem ,afirmować istnienie jakiegoś bytu albo jakiejś rzeczy, to w sumie mówić: ten byt albo ta rzecz jest tej samej natury co moje ciało i należy do tego samego świata; tylko że ta jednorodność dotyczy bez wątpienia nie tyle istoty (obiektywnej), co in t y m ności zawartej w słowie mój, moje ciało" (JM s. 305). To, co pierwotne - to zatem intymność, bliskość, dobroć.

Otóż skoro jednorodność nie musi dotyczyć takich samych, a więc cielesnych treści, lecz analogicznej i równie niepowątpiewalnej blis k ości, to wcielenie może się stać prototypem innych, głębszych i duchowych więzi - w tym sensie, jak pisze Marcel „wiara powin na uczestniczyć w naturze wrażenia” (JM s. 131). Ale intymność naszego pierwotnego, nieświadomego jeszcze zanurzenia w rzeczywistości uwyraźnia się dopiero w intymności z „drugimi”, z ludzkim, a zwłaszcza Boskim „ty”, w relacji diadycznej. Uwyraźnia, choć zarazem poddawana jest nieustannym „próbom”, które z istniejącego ludzkiego podmiotu czynią dramatyczną e gzy ste ncję.

Relacja diadyczna: ja-ty definiuje się w przeciwstawieniu do relacji triadycznej: ja-ty-on. Ta ostatnia relacja jest typowa dla każdego dyskursu słownego: w każdym dialogu, jaki toczę z kimś n a ja k iś t e m a t, temat ów jest „trzecim”, „nim” w stosunku do nas. Nieustannie mówimy nie tylko o czymś, lecz o kimś, lub o nas samych, traktując wówczas siebie lub drugich podobnie jak rzeczy: jakby z obojętnym dystansem, jak nieobecnych. W relacji diadycznej sytuacja ta jest niemożliwa: ty i ja jesteśmy dla siebie nawzajem o be c n i, w intymnej bliskości, której miłość jest najdoskonalszą postacią i która bynajmniej nie ogranicza się do obecności fizycznej: ktoś zmarły może być dla mnie bardziej obecny niż ktoś kto siedzi przy mnie.

Bliskość relacji diadycznej domaga się innego typu dialogu, nazywanego przez Marcela „inwokacją” - wzywaniem, „abyś był ze mną”, w łonie już jakoś zaistniałej między nami wspólnoty, która jednak zakłada w oln ość i dlatego ludzkie „ty” może się z niej zawsze wyłamać. Inaczej Bóg: tylko w stosunku do „Niego”, choć jest najdoskonalej wolny, sytuacja ta jest nie do pomyślenia, gdyż ani Bóg dla mnie, ani ja dla Boga nie mogę stać się oboję t ny m: „Bóg jest Ty Absolutnym, który nie może nigdy stać się Nim” (JM s. 137). Dopiero relacja diadyczna, przede wszystkim z „Ty Absolutnym”, jest we właści- 
wym sensie partycypacją: ,stosunek diadyczny jest tym, co w mych poprzednich poszukiwaniach nazwałem partycypacją" (JM s. 155).

Otóż Marcel uświadamia sobie coraz bardziej, że ta partycypacja par excellence ma charakter on tolo g i c z n y: bliskość z ludzkim i boskim „ty” jest „co-esse”, współbyciem w łonie najgłębszego wymiaru partycypacji, jakim jest „tajemnica ontologiczna”. Droga do odkrycia tego wymiaru biegnie poprzez „wymóg transcendencji”, który drąży nas nieświadomie od początku, poprzez wszystkie doświadczenia życiowe.

\section{Tajemnica ontologiczna}

Wymiarowi egzystencjalnemu i subiektywnemu towarzyszy - mający swe źródło w dramatyczności naszych konkretnych sytuacji w świecie — „niepokój metafizyczny”, który nie jest żadną „transcendentną ciekawością”, lecz poszukiwaniem absolutnej orientacji w życiu i zarazem tego, co Marcel nazywa rozprężeniem się czy wyprostowaniem: „Umysł jest metafizyczny, o ile jego pozycja w stosunku do rzeczywistości jawi się mu (stała się dla niego) jako z gruntu nie do zaakceptowania [...]. Chodzi o to, żeby się rozprostować albo żeby się rozprężyć. Metafizyka jest tym wyprostowaniem się albo rozprężeniem" (JM s. 279). Co przede wszystkim rodzi ten niepokój i tę nieakceptację? Postawa posiadania i jej konsekwencje.

Posiadanie w rozumieniu marcelowskim nie ma wiele wspólnego z fizycznym posiadaniem rzeczy; jest raczej tendencją do manipulowania dla własnej korzyści wszystkim, co nie jest mną. Podstawowym warunkiem możliwości posiadania jest zatem rozerwanie naszej intymnej więzi z bytem i wyraźne ukonstytuowanie się owego „nie” między mną a rzeczywistością — w postaci ściśle określonych przedmiotów podatnych na zawładnięcie. Mają one parę właściwości.

Po pierwsze są względem mnie ze wnętrzne - sam dla siebie też mogę być takim zewnętrznym przedmiotem - przy czym między tą „,zewnętrznością”, a moją „wewnętrznością” panuje od razu charakterystyczne napięcie: przedmioty te jawią się tym bardziej niedosiężne i zewnętrzne, im bardziej ich pragnę, to znaczy im bardziej mnie wewnętrznie dotykają i przez to zniewalają, nie mogąc nigdy stać się mną.

Po drugie, to, co posiadane, musi dać się określić, scharakteryzować i w ten sposób staje się podmiotem możliwych do zweryfikowania własności (przedmiot sam także „posiada własności”). Otoż to, co charakteryzowalne - przedmiot - jawi mi się jako w stosunku do mnie ob oj ę t ne: „myśleć przedmiot, to, jak się wydaje, myśleć coś, dla czego ja się nie liczę" (JM s. 279).

Po trzecie to, co charakteryzowalne jako takie jest wyczerpywalne i dlatego skończone, a przez to staje się okazją do rozpaczy: to, co daje się 
zinwentaryzować, jest okazją do rozpaczy (policzyłem, nie wystarczy mi)". W ten właśnie sposób jawi się dla nas idea nicości: jako kres tego, co przeliczalne, np. chwil życia: „rozpacz jako wstrząs, który dusza odczuwa w zetknięciu ze stwierdzeniem: nie ma nic poza tym" (EA s. 148). Oto najgłębsza geneza nihilizmu, który idzie w parze $\mathrm{z}$ naszym buntem, poczuciem zdrady ze strony świata, a także nieraz — Boga. Bóg jest jednak Tym, który nie może zdradzić, ale który m. in. właśnie dlatego nie daje się w żaden sposób scharakteryzować i wyczerpać.

Po czwarte wreszcie, posiadanie czyni nas o b c y mi i niezrozumiałymi dla samych siebie: uprzedmiotawiając rzeczywistość wraz z sobą zamykamy się w sobie i przez to rodzimy w sobie i wokół nas nieprzezroczystość, ciemność: „należy zerwać raz na zawsze z metaforami, które przedstawiają świadomość jako świetlisty krąg, wokół którego rozciągają się dla niej tylko ciemności. Przeciwnie, ciemność jest w samym środku" (EA s. 15). Ale w ten sposób rodzi się w nas rozpaczliwe pytanie: kim właściwie jeste m?

Otóż pytanie to, zarówno jak bunt przeciwko nicości, zakłada pojęcie b y ci a. Pojęcie to jest dla Marcela korelatem „wymogu ontologicznego”, a więc tego, czego najgłębiej pragnę, a nawet więcej: wymagam. Co to takiego? Wymóg ontologiczny to, po pierwsze, wymóg sensu ży cia: „Trzeba aby było [...] by cie, aby wszystko nie redukowało się do gry pozorów, następujących po sobie i niespó j n y ch [...] lub do historii opowiedzianej przez idiotę, by podjąć wyrażenie Szekspira” (PA s. 261). Pozorność wiąże się z niemożnością dotarcia do prawdy o nas samych, naszej sytuacji w świecie, naszych związków z drugimi, a równocześnie ma ścisły związek ze skończonością, cierpieniem, śmiercią. Dlatego wymóg ontologiczny to, po drugie, wymóg trwałości, czegoś na czym się można oprzeć: „bycie jest tym, co opiera się — albo byłoby tym, co by się opierało - wyczerpującej analizie, dotyczącej danych doświadczenia i dążącej do stopniowego zredukowania ich do elementów coraz bardziej pozbawionych wewnętrznej wartości, lub znaczenia" (PA s. 262). Trwałość to zatem trwałość wartości nieodłącznych od bytu, jego „obecności”, która sama już jest wartością. Dlatego wymóg ontologiczny dotyczy po trzecie niezniszczalnej „o b e c n ości, tej wewnętrznej realizacji obecności w łonie miłości, która przekracza nieskończenie możliwą weryfikację, gdyż rozgrywa się wewnątrz bezpośredniości, która sytuuje się ponad wszelkim możliwym do pomyślenia pośrednictwem" (PA s. 263). Przekraczając możliwą weryfikację, „obecność” przekracza zarazem możliwe dementi, które może płynąć ze strony śmierci; wymóg ontologiczny — to zatem w sposób istotny wymóg nieśmiertelności.

Inaczej mówiąc wymóg ontologiczny to wymóg jakiegoś „naprawdę”, którego nie ma bez jakiegoś „na zawsze”. Jest to więc imperatyw pr ze k racza$\mathrm{n}$ i a tego, co skończone, niepewne i dlatego zawsze w drodze ku jakiejś pe $1 \mathrm{n}$ i, bez której droga ludzka była by pozbawiona busoli. Dla Marcela jednak ta dro- 
ga ku pełni jest filozoficznie możliwa tylko pod warunkiem rozpoznania jej sytuacji wyjściowej, którą jest dokonująca się j u ż nasza indywidualna „partycypacja w byciu" - pod warunkiem, że się na nią naprawdę otworzymy. Jak ją jednak rozpoznać?

Zastanówmy się chwilę nad pytaniem: kim jestem? Dla idealisty pytanie to zmieniłoby się natychmiast $\mathrm{w}$ afirmację transcendencji pytającego umysłu nad każdą odpowiedzią, każda bowiem odpowiedź jest wszak dla pytającego, skoro dla umysłu jest każdy w ogóle element wiedzy. Ale w wypadku tego właśnie pytania podmiot pytający musi uznać, że nie jest n a ze w n ą t $\mathrm{r}$ z samego pytania, a więc i odpowiedzi, owo bowiem ,jestem” jest tu już od początku w nim samym założone. W ten sposób „moje pytanie o bycie zakłada afirmację, w której byłbym w pewnej mierze pasywny i której byłbym raczej miejscem niż podmiotem”. Wskutek tego „znajdujemy się tu wobec pewnego porywu ku afirmacji, która w ostateczności nie może zostać dokonana, gdyż nie mogę uznać się za uprawnionego do wypowiedzenia jej inaczej niż w oparciu o nią samą" (PA s. 266). Pytanie o bycie doprowadza więc do kapitulacji podmiotu idealistycznego. Ale w ten sposób podmiot ten otwiera się dopiero na najbardziej podstawowy wymiar rzeczywistości, w którym od początku partycypuje.

Wymiar ów określa Marcel jako tajemnicę ontologiczną i przeciwstawia temu, co „problemowe”: podczas gdy problem jest zawsze przede mną i mogę nad nim tak czy inaczej zapanować, w wypadku tajemnicy nie jest to możliwe. Znika tu więc sensowność przeciwstawienia tego co wewnątrz i tego, co na zewnątrz, wskutek czego „partycypacja ta nie może, z samej definicji być przed mi o t e m myśli" (PA s. 267), przekracza zatem sferę posiadania i problemów: jest „metaproblemowa”.

Okazuje się więc, że w tajemnicę ontologiczną podmiot jest od początku „zaangażowany”, ale w taki sposób, że może się jej zarazem wyprzeć: „zawsze jest możliwe (logicznie i psychlogicznie) zdegradowanie tajemnicy do zrobienia z niej problemu”, a „z faktu, że do istoty tajemnicy należy, iż jest rozpoznana lub możliwa do rozpoznania wynika także, że może być nie poznana lub czynnie negowana" (EA s. 170).

Otóż dla Marcela najgłębszym sposobem uczestnictwa w tajemnicy jest nie co innego, jak wiara w Boga; co więcej, uczestnictwo to, o ile rzeczywiście się dokonuje, jest - czy o tym wiemy czy nie - wiarą. W jaki sposób? Zanim odpowiemy na to pytanie, musimy najpierw zapytać, czym dla Marcela jest wiara.

\section{TEORIA WIARY}

Zobaczmy najpierw czym dla niego wiara nie jest. Wiara nie jest „opinią”. Opinia jest czymś pośrednim między „wrażeniem” na temat czegoś („mam 
wrażenie, że”), a zdecydowaną afirmacją. Subiektywne „wrażenie” nabiera przy tym w opinii - według Marcela - charakteru obronnego i sztywnieje w niby-obiektywne „uważanie, że”, które z kolei często wskutek identyfikacji z jakimś środowiskiem socjologicznym przemienia się w pozbawione tolerancji „każdy wie, że”. Charakterystyczny jest tu wszędzie d y st a n s wobec obiektu opinii - oto dlaczego niemożliwa jest opinia na temat oșób naprawdę bliskich, a tym bardziej - Boga.

Wiara nie jest jednak także „przekonaniem”. Przekonanie jest czymś zasadniczo zamknięty m: zakłada, że albo mogę z góry przewidzieć wszystkie możliwe zarzuty przeciwko mym przekonaniom, albo, że mimo tych zarzutów mych przekonań nie zmienię. Jedno i drugie stanowisko jest jednak w istocie bezprawne, ponieważ ani nie mogę przewidzieć wszystkich możliwych zarzutów, ani moich własnych na nie reakcji. W przeciwieństwie do tego wiara jest otwarta na czas: nie jest bowiem po prostu „wiarą, że”, lecz przede wszystkim „wiarą w”, która zakłada zarówno po stronie Boga jak człowieka wolność (RI s. $171-175)$.

Wiarą nie jest także żadną „hipotezą” na temat Boga. Hipoteza dotyczy zawsze tego, co da się sprawdzić, a więc tego, co obiektywne — zaś obiektywność zakłada $\mathrm{z}$ istoty wymienialność obserwatora, który postawiony na moim miejscu może ewentualnie skorygować to, co obserwuję, gdyż ma lepszy wzrok itd. („Tw o j a góra jest w istocie chmurą"). Tymczasem wiara jest $\mathrm{z}$ istoty najgłębiej os obisty m odniesieniem do „Absolutnego Ty” i nie mogę z nikim zamienić się miejscem wobec owego Ty, ponieważ po prostu j e s t e m moim miejscem (JM s. 303). Nie znaczy to, że wiara jest czymś subiektywnym: kategorie obiektywizmu są tu, tak jak w tajemnicy, przekroczone.

Czym zatem jest wiara? Jak ją można określić i uprawomocnić wobec rozumu filozoficznego? Pojęcie wiary pojawia się u Marcela od razu na początku jego rozważań nad teorią partycypacji, lecz ulega znamiennej ewolucji. Jest to ewolucja od określonego dziedzictwem idealistycznym „indywidualizmu” do współuczestnictwa z drugimi w dramatycznej drodze ku pełni coesse, współbycia $\mathrm{z}$ innymi podmiotami w miłości.

\section{Od „akceptacji bycia zaakceptowanym” do dialogu}

Nie tylko chimeryczna wiedza absolutna, ale wszelka pojęciowa wiedza jest dziełem podmiotu myśli ogólnej, określającego siebie jako cogito, dla którego wszelka prawda jest prawdą. Otóż cogito tworzy nieuleczalne dualizmy: tego, co ogólne i co empiryczne, ducha i materii, tego, co realne i co idealne itd. Lecz owo „myślę" odkrywa siebie jako tożsame z pewnym konkretnym ,ja”, które jednak cogito klasyfikuje jedynie jako egzemplarz — w istocie niezrozumiały — tego, co ogólne”, jako „to, co empiryczne”. Tymczasem w ol n o ść u podło- 
ża cogito ch ce siebie jako pewnej nierozkładalnej całości, z której wszakże myśl ogólna nie może zdać sprawy. Pod jakimi więc warunkami mogę tę całość pomyśleć jako sensowną? O ile ją zrozumiem jako dar drugie j woln ości, to znaczy jako stworzoną i miłowaną przez inną, Boską wolność, „przez bezczasowy akt, który jest związany ze mną bez żadnych pośrednictw" (JM s. 6). Ale w ten sposób muszę również przestać uważać za przypadkowy świat, „ze względu na immanentny związek, jaki łączy mnie ze światem i powoduje, że jestem" (tamże).

Inaczej mówiąc, „wolna indywidualność może siebie określić tylko przez odniesienie do wolności boskiej, myśląc świat jako twór tej wolności” (FP s. 105). Na tym właśnie polega wiara, która — zabraniając sobie jakiejkolwiek „substancjalizacji” Boga - musi jednak afirmować Jego rzeczywis tość. Na zapytanie bowiem „czy Bóg nie wyczerpuje się w subiektywnych afirmacjach, które wydają się Go rodzić?” trzeba odpowiedzieć: „ta wiara w Boga sprowadza się do afirmacji, że duch sam jest uwarunkowany przez Boga, to znaczy do afirmacji Ojcostwa Bożego. Znaczy to, że duch ustanawia (pose) Boga jako ustanawiającego (posant) jego” (JM s. 46). Wyraźniej jeszcze: „akt wiary implikuje przyjęcie Boga jako niezależnego od aktu, który Go przyjmuje” (JM s. 58). Niezależnego - ale zarazem ,pochylającego" się nade mną ze swą ojcowską miłością.

Co więcej, wraz z teorią Absolutnego Ty staje się jasne, że Bóg musi być myślany jako przeciwieństwo przedmiotu, a więc jako Ktoś, kto nie może być wobec mnie obojętny: „myśleć Boga jako rzeczywistego to afirmować, że jest dla Niego ważne, iż w Niego wierzę, podczas gdy myśleć stół, to go myšleć jako całkowicie obojętny wobèc faktu, że go myślę. Bóg, którego nie interesowałaby moja wiara, nie byłby Bogiem, lecz zwykłym jestestwem metafizycznym" (JM s. 155). Naturalnie może znowu w tym momencie powstać wątpliwość, czy „Ty Absolutne nie jest jedynie idealną granicą, w stronę której zdąża jakakolwiek miłość, w stopniu, w jakim się oczyszcza, filtruje, eliminuje wszystkie elementy egoizmu i niepokoju, jakie zawiera?" (JM s. 275). Odpowiedź brzmi, że trzeba rozróżnić Ty, które byłoby je dy ni e granicą i Ty, które jest w i ę c e j niż granicą; przy czym ,nie mogę powiedzieć, że jest Ono jedynie granicą, nie przeciwstawiając Go Ty rzeczywistemu, ale myślanemu jako u ro jo ne (gdyż zarzut chce wykazać, że Ty Absolutne jest nierzeczywiste - K.T.). Lecz twierdzić, że Ty nie jest rzeczywiste [...] to przekształcić Je w nie go" (JM s. 278), to znaczy w urojony przedmiot. Zarzut więc, podobnie jak w poprzednim przypadku, rozmija się $z$ tym, co tu kluczowe: $z$ istoty wiary płynącą nierozdzielnością Boga od wiary.

Wynikają z tego dwie zasadnicze konsekwencje. Po pierwsze niemożliwy jest — raz jeszcze - dowód na istnienie Boga, ponieważ dowodzić można czegoś tylko o przedmiocie: „to, czego istnienie mogłoby być udowodnione, nie byłoby, nie mogłoby być Bogiem" (JM s. 223). Po wtóre, nie jest możliwy dys- 
kurs pojęciowy o Bogu: „gdy mówimy o Bogu wiedzmy, że nie o B o g u mówimy” (JM s. 158). Mogę jedynie „myśleć o...” Bogu, czyli „być z Bogiem”; ale być z Nim, to nic innego, jak się modlić, gdyż modlić się, to aktywnie odmawiać myślenia Boga jako porządku, to myśleć Go naprawdę jako Boga - jako czyste Ty" (JM s. 159). Bóg wiary to zatem w sposób is t o t n y Bóg dialogu.

Bóg jednak może - co Marcel widzi coraz wyraźniej — być dla mnie „Absolutną Obecnością" i Ty Absolutnym nawet w sposób ukryty i niejasny, lecz prawdziwy i rzeczywisty. Ale jak? W tym miejscu musimy powrócić do idei tajemnicy ontologicznej.

\section{Wiara a tajemnica ontologiczna}

Stwierdziliśmy, że tajemnica ontologiczna jest „porywem ku afirmacji” bycia, wypływającym z „wymogu ontologicznego”. Jak ów poryw się przejawia?

Według Marcela, u podstaw ujęcia tajemnicy ontologicznej jest coś takiego, jak „oślepiona intuicja”: „wydaje mi się, że jestem - powiedzmy na pewnym poziomie mojego ja - wobec Bytu; w pewnym sensie go widzę - w innym sensie nie mogę powiedzieć, że go widzę, gdyż nie ujmuję siebie jako widzącego. Ta intuicja nie poddaje się i nie może się poddawać bezpośrednio refleksji. Lecz oświetla ona cały świat myśli, ku któremu się zwraca - przekraczając go. Nie widzę, jak można inaczej wyrażając się metafizycznie ująć wiarę" (EA s. 142); cały świat myśli, czyli przede wszystkim rozmaite ludzkie d oświadczenia, którym trzeba „przywrócić ich wagę ontologiczną" (EA s. 149). Tylko poprzez analizę tych doświadczeń możemy odzyskać ową zagubioną intuicję, dającą o sobie znać poprzez obecny w nas „niepokój metafizyczny".

Otóż doświadczenia ludzkie mają to do siebie, że są ciągiem p rób. W każdej próbie jest po pierwsze uwikłana st a w k a próby, która może być zgubiona lub ocalona, a którą jestem ja sam, mój byt, czyli „moja dusza”. Po drugie w próbach życiowych ujawnia się to, co „się w życiu opiera, a co nie, co się ulatnia, a co zostaje na dnie tygla" (JM s. 178), następuje więc coś w rodzaju filtrażu wartości, który odcedza to, co naprawdę j es t - a więc „bycie”. W próbie krystalizuje się kształt ludzkiej wolności i dlatego jest ona „samym polem wolności" (JM s. 229), która to wolność zdobywa się - lub nie - na tra n s ce nd ow a ni e, na przekraczanie tego, co człowieka ogranicza, a także co go skłania do zamknięcia się w sobie i do rozpaczy.

Dlatego „konkretnych dróg dojścia do tajemnicy ontologicznej należy szukać nie tyle w dziedzinie myśli logicznej [...], ile raczej w wyjaśnianiu pewnych czysto duchowych danych, takich jak wierność, nadzieja, miłość, w których człowiek ukazuje nam się $\mathrm{w}$ walce $\mathrm{z}$ pokusą zaparcia się, zamknięcia $\mathrm{w}$ samym sobie, wewnętrznego skostnienia” (EA s. 173). Na przykład nadzieja polega 
na ruchu transcendowania poszczególnych celów czy wartości, tak aby nie zamykać się w obliczu pozornie ostatecznej klęski, jak, powiedzmy, niewyzdrowienie ze śmiertelnej choroby, gdyż „sama idea wyzdrowienia może, przynajmniej w pewnej sferze duchowej, oczyścić się i przemienić" (HV s. 58 - 59). Podobnie, jak miłość, która wyczekuje nieśmiertelności kochanej osoby i samej siebie, albowiem tylko dzięki niej mogłaby zostać osiągnięta - jakby utracona - jedność mnie ze sobą samym i z drugim „ty”2.

Ze wszystkich tych dróg najważniejsza wydaje się jednak Marcelowi wierność, która jawi mu się wręcz jako model wiary. Dlaczego? Przede wszystkim nie da się pomyśleć wierności bez założenia czegoś absolutnie trwałego, co przekracza czas. Wierność ,jest w istocie uznaniem, nie teoretycznym czy werbalnym, lecz rzeczywistym, pewnej niezmienności ontologicznej, która trwa i w stosunku do której my trwamy, niezmienności, która zakłada czy wymaga historii - w przeciwieństwie do martwej czy formalnej niezmienności tego, co czysto powinnościowe, pewnego prawa" (EA s. 173-174). W próbie twórczej wierności wobec kogoś bliskiego, czy też naszego powołania, sprawdza się nasza podatność na „uchwycenie" przez ową Niezmienność, która jest samym Byciem. W ten sposób bycie jawi się jako „miejsce wierności” (EA s. 55), a zarazem jako to, co samo „nie zawodzi” i co spełnia nasze najgłębsze oczekiwania - „mówię o tym oczekiwaniu, w którym uczestniczymy całym sobą" (JM s. 177). Oto dlaczego można i trzeba utożsamić tajemnicę bycia i tajemnicę zbawienia (JM s. 180).

Otóż to przekraczanie w próbach naszej skończoności ku nieskończonemu byciu jest możliwe i dokonuje się tylko dzięki wi e rze: „wierzący to ten, kto nie natrafi na żadną niepokonalną przeszkodę na tej drodze transcendencji" (HV s. 59). W ten sposób droga ta okazuje się też sama jedną wielką próbą wiary, której zresztą wiara ta się domaga: „wiara jest $\mathrm{z}$ istoty czymś, co powinno i chce być wypróbowane” (JM s. 198). Na czym jednak w perspektywie „konkretnych przystępów do tajemnicy ontologicznej" zasadza się rdzeń tej wiary? Na nieograniczonym, choć nie zawsze uświadomionym kredycie zaufania, na za wi e r ze niu: „Otworzyć komuś kredyt, oto, jak mi się zdaje, działanie naprawdę konstytutywne dla wiary jako takiej" (MER II s. 78). To otwarcie kredytu przemienia zwykłą „wiarę, że”, wiarę w pewne fakty - w „wiarę w...”. Jeśli wierzę w... kogoś, to obdarzam zaufaniem je go wie rność mówiąc: „jestem pewny, że nie zawiedziesz mego oczekiwania, że na nie odpowiesz, że je wypełnisz [...]. Można mieć zaufanie tylko do jakiegoś «ty〉, od rzeczywistości zdolnej do funkcjonowania jako 〈ty〉, zdolnej do bycia wzywaną i do stania się ucieczką” (RI s. 177). Poprzez próby Bóg wyłania się jako „Absolutna Ucieczka", która nie może zawieść. $499 n$.

2 W. Levin as, M. Buber et G. Marcel, „Revue Internationale de Philosophie” $126: 1978$ s. 
Lecz jak rozpoznać tę „Absolutną Ucieczkę”, która jest zarazem — jak możemy się domyśleć - „Absolutnym Ty? Czy to pytanie ma w ogóle sens? Marcel proponuje tu $\mathrm{m}$. in. analizę wezwania jako takiego w łonie dążenia do p r a w dy o sobie, które już doprowadziło nas do odkrycia tajemnicy ontologicznej. Gdy pytam „kim jestem” znajduję się — jak pamiętamy — wobec „porywu ku afirmacji”, która w ostateczności nie może zostać dokonana. Lecz ów poryw nie jest przez to bynajmniej ugaszony — dalej wszak co do tego kim jestem pozostaję w ciemności. W obliczu odkrycia tajemnicy ontologicznej przemienia się on jednak niepostrzeżenie w wezwanie, apel. Otóż „może w tej mierze, w jakiej zdaję sobie sprawę z tego we zwa nia jako we zwania, zmuszony jestem przyznać, że to wezwanie jest możliwe tylko dlatego, że w głębi mnie samego znajduje się coś innego niż ja sam - i tym samym wezwanie zmienia znak” (EA s. 181). Kolejne pytanie o to, czy na moje wezwanie „ktoś odpowiedział" czy nie, jest tu pozbawione sensu, gdyż mógłbym to wówczas jedynie stwierdzić lub nie stwierdzić, czyli pozostawałbym na płaszczyźnie przedmiotowej hipotezy, a więc - problemu. Tymczasem jeśli zrozumiem sens mojego wezwania jako takiego, okaże się, że jest ono możliwe tylko jako odpowiedź w łonie intymnego „sam na sam” z Absolutnym Ty.

Właśnie w ten sposób jawi się sobie wiara: jako odpowiedź - „odpowiedź na co? Trudno to wyrazić; na niejasne, milczące zaproszenie, które wypełnia duszę, albo inaczej mówiąc wywiera na nią nacisk, ale jej nie przymusza" (EA s. 310). Tak rozumiana wiara w Boga jako Absolutną Ucieczkę, Absolutną Trwałość, Absolutnego Swiadka ,jest moim byciem, jest naprawdę sednem tego, czym jestem" (RI s. 223), sposobem, w jaki jedynie mogę naprawdę być sobą. Trzeba tu jednak zwrócić uwagę na dwie sprawy: po pierwsze wiara nie jest - powtórzmy - „wiarą kogoś jednego w kogoś drugiego”; nie jest to „opinia, którą ma A na temat B” (RI s. 220). Jest to raczej „fakt pozostawania na otwartym obwodzie względem rzeczywistości rozpoznanej jako pewne 〈Ty〉, porównywalnej do 〈Ty〉" (RI s. 222). Bóg nie jest Kimś na zewnątrz mnie, i dlatego między Nim a mną niemożliwa jest relacja pana do niewolnika, lecz jedynie relacja miłości. Po drugie jednak: czy naprawdę ,jestem moją wiarą"? $\mathrm{Na}$ to pytanie trzeba uczciwie odpowiedzieć: „Jasne jest, że nie [...]. O ile nie jestem przeźroczysty, o tyle nie wierzę. Niedowiarstwo i nieprzeźroczystość mieszają się ze sobą" (RI s. 223).

Jeśli jednak zdam sobie z tego sprawę, może się nawiązać rzeczywista wspólnota między mną a niewierzącym, której na próżno poszukiwały dowody na istnienie Boga. Może być bowiem z jednej strony tak, że drugi, „który oświadcza, że jest niewierzący, bardziej prawdziwie, bardziej skutecznie ode mnie, który uważam się za wierzącego, poświadcza rzeczywistość zawartą w moim akcie wiary” (tamże). Wiara nie jest bowiem „wyraźnym uchwyceniem Boga jako kogoś drugiego”, lecz raczej wiernością względem pewnego „światła”, któremu można dawać świadectwo, lub się go wyprzeć; a „czyż do istoty tego, 
co ontologiczne, nie należy to, że może być ono jedynie poświadczone?" (EA s. 143).

Skoro jednak mogę zauważyć, że niewierzący lepiej świadczy o Bogu niż ja sam, to - z drugiej strony — dlatego, że moje i twoje „ni e wi e r zę wyjaśnia się tylko poprzez początkowe w i e r z ę, które jest raczej ograniczane, niż unieważniane" (RI s. 223). Jest tak dlatego, że w głębi nas samych, czy wiemy o tym, czy nie, „NIE JESTEŚMY DLA SAMYCH SIEBIE” (EA s. 165), co Emmannuel Levinas w artykule o Marcelu tak komentuje: „Byt boski, którym nie jesteśmy, Ty Absolutne, które spotykamy jako transcendentne, jest także byciem, które nas niesie i kocha"2. Dlatego partycypacja w Bogu przez wiarę nie jest alienacją ani woli, ani rozumu, lecz wyzwoleniem dopiero całego człowieczeństwa.

Czy marcelowska filozofia wiary jest irracjonalizmem i fideizmem? $\mathrm{Z}$ tego, że nie uważa on za jedynie prawomocny w filozofii w ogóle, a w szczególności w filozofii Boga, pewien typ racjonalności i metody myślenia, nie wynika jeszcze żaden irracjonalizm; przeciwnie, irracjonalne jest uznawanie tylko jednego typu racjonalności. Rdzeniem intuicji filozoficznej Marcela jest przeświadczenie, że filozofia Boga, która nie rozpoczyna od badania warunków możliwości osobistej, in d y w i d u a ln e j relacji między Bogiem a człowiekiem (albo zgoła tę relację poza obręb filozofii wyrzuca), jest właśnie nieracjonalna, bowiem Bóg jest prze de ws zy st k i m Tym, Kto nas obchodzi i ma dla nas osobiste znaczenie: nie można arbitralnie brać w nawias tego, co podstawowe. Jest on przekonany, że relacja do Boga ma miejsce u każdego człowieka, lecz może ona nie być rozpoznana; co więcej, do jej istoty należy to, że może nie być roz pozn an a i u znana, ponieważ ,wolność nie może być inaczej afirmowana, jak tylko przez inną wolność", a nie przez bezosobowe dowody, angażujące tylko intelekt, a nie całego człowieka. Oto dlaczego interesuje go logika egzystencjalna, logika wolności, która nie jest arbitralna, ponieważ jej własną rozumnością jest wymóg pełni nasyconych miłością więzi międzyosobowych, które jedynie naprawdę wyzwalają naszą wolność z „pokus zaparcia się, zamknięcia w samym sobie, wewnętrznego skostnienia". Wymóg, który może się jednak zrealizować tylko, o ile już teraz otworzymy się na bijące $\mathrm{z}$ naszego wnętrza tajemnicze we zwanie, które poprzez próby ujawnia nam się jako podstawa naszych wierności i naszych nadziei. Wiara na tym właśnie polega. $499 \mathrm{n}$.

${ }^{2}$ W. Levinas, M. Buber et G. Marcel, „Revue Internationale de Philosophie” $126: 1978 \mathrm{~s}$. 
Marcel zakłada, że osobiste, indywidualne otwarcie się na owo wezwanie może być jednak ułatwione przez uznanie naszej partycypacji w tajemnicy ontologicznej, w której jest możliwe wzajemne przenikanie się tego, co „transcendentne” i tego, co „immanentne”. Gdyż tylko wtedy możemy zrozumieć możliwość sytuacji, w której Drugi, który n i e jest mną, lecz Nieskończonym i Transcendentnym, jest równocześnie Tym, który jest bardziej we mnie niż ja sam — sytuacja nie do pomyślenia przy przyjęciu kryteriów racjonalności jedynie typu przedmiotowego. Możliwość ta chroni nas również poniekąd przed pokusą prometejskiego ateizmu, dla którego Bóg jest jedynie zewnętrznym, wywołującym głuchą rewoltę, panem. Idea tajemnicy ontologicznej wydaje się więc nieść światło, które pomimo swej niejasności pozwala wglądać w istotnie dialogiczną i religijną naturę ludzkiego doświadczenia świata i - last but not least - ułatwić ludzkiej wolności opowiedzenie się raczej za urzeczywistnieniem tej natury, niż za jej przekreśleniem.

\section{GABRIEL MARCEL — LA PHILOSOPHIE DE LA FOI}

\section{Résumé}

La philosophie de la foi constitue le fond même de la philosophie marcélienne, peu connue en Pologne, malgré la traduction de certaines de ses oeuvres.

Le point de départ de cette philosophie est la critique des rationalismes divers: de la théorie hégelienne du savoir absolu, du scientisme de Léon Brunschvicg et, finalement, du thomisme. A tous ces rationalismem Gabriel Marcel oppose sa théorie de la participation, dont les moments principaux sont: une nouvelle idée de l'existence, l'idée de la relation dyadique et la découverte de la dimension du mystère ontologique. L'élaboration - bien que peu systématique de cette grande théorie lui a permit de trouver une nouvelle approche à la réalité, destinée surtout à jeter les bases pour la nouvelle philosophie de Dieu et pour une anthropologie religieuse.

La théorie marcélienne de la foi a parcouru certaines étapes selon la ligne du développement de sa philosophie toute antiere. L'étape première indique une „explosion" de l'idéalisme par la relation croyante à Dieu qui me constitue en tant qu'individu irréductible à toutes les constructions de la „pensée en général”.

L'etap seconde déssine les traits caracteristique de cette relation comme une relation ,dyadique”, dans laquelle Dieu se montre, pour l'homme „Toi Absolu” impossible à circonscire par une pensée objectivante, mais accessible à d'autres modes de la pensée et - surtout - à la prière.

L'etape décisive consiste à scruter les mouvements du „transcender” qu'un individu humain immergé dans les relations intersubjectives parcourt à travers les épreuves de la vie ou la liberté décide d'elle-même en s'ouvrant à l'Étre divin dans la foi qui est l'etoffe même de l'espoir, de la charité et surtout de la fidélité - ou bien en s'enfermant dans le désespoir et l'égocentrisme finalement démoniaques.

Or, en approfondissant l'idée de la fidélité Gabriel Marcel trouve son essence dans le „crédit” que j'ouvre à un Toi qui ne peut pas me décevoir, parce qu'Il est un Permanent ontologique qui, en tant que Toi Absolu ne peut pas me prendre en considération et me trahir. Mais la fidélité ainsi 
conçue n'est rien d'autre que la foi comme foi...à, à l'encontre de la foi comme foi que... Cette foi à...est une réponse a un appel qu'on peut rencontrer dans notre intériorité recueillie ou a une lumiere qui nous pénetre. Cette foi constitue le fond de ce que nous sommes, de notre être qui toute fois est plutot un „scientillement” de la foi et de l'infidélite, grâce à quoi nous pouvons communier avec les incroyants qui se pensant tels peuvent néanmoins temoigner de la lumiere et de l'appel mieux que moi, car la réponse peut ne pas être consciente sans cesser d'étre une réponse authentique.

La théorie de la foi chez Gabriel Marcel ne semble pas être un fidéisme - elle nous ouvre plutot à d'autres dimensions de la rationnalité que celles dont s'occupait la métaphysique traditionnelle. 